\title{
The Effect of Annealing on The Structural and Optical Properties of Copper Oxide Thin Films Prepared by SILAR Method
}

\author{
Hayder M. Ajeel* \\ Ashwaq A. Jabor*
}

\author{
Shatha S. Batros Jamil* \\ Elham H. Nassir*
}

Received 20, December, 2012

Accepted 11, March, 2014

\begin{abstract}
:
Copper oxide thin films were deposited on glass substrate using Successive Ionic Layer Adsorption and Reaction (SILAR) method at room temperature. The thickness of the thin films was around $0.43 \mu \mathrm{m}$.Copper oxide thin films were annealed in air at (200, 300 and $400^{\circ} \mathrm{C}$ for $45 \mathrm{~min}$. The film structure properties were characterized by $\mathrm{x}$ ray diffraction (XRD). XRD patterns indicated the presence of polycrystalline $\mathrm{CuO}$. The average grain size is calculated from the X-rays pattern, it is found that the grain size increased with increasing annealing temperature. Optical transmitter microscope (OTM) and atomic force microscope (AFM) was also used. Direct band gap values of $2.2 \mathrm{eV}$ for an annealed sample and $(2,1.5,1.4) \mathrm{eV}$ at $200,300,400^{\circ} \mathrm{C}$ respectively.
\end{abstract}

Key words: Copper oxide thin films, SILAR, Thermal annealing

\section{Introduction}

Copper oxides are semiconductors that have been studied for several reasons such as the natural abundance of starting material copper $(\mathrm{Cu})$; the easiness of production of $\mathrm{Cu}$ oxidation; their non-toxic nature and the reasonably good electrical and optical properties [1]. Copper forms two wellknown oxides: tenorite $(\mathrm{CuO})$ and cuprite $\left(\mathrm{Cu}_{2} \mathrm{O}\right)$. Both the tenorite and cuprite were p-type semiconductors having band gap energy of 1.21 to 1.51 $\mathrm{eV}$ and 2.10 to $2.60 \mathrm{eV}$ repectively. As a p-type semiconductor, conduction arises from the presence of holes in the valence band (VB) due to doping/annealing. The unit cell parameters of $\mathrm{CuO}$ is $\mathrm{a}=4.684 \mathrm{Ao}$, $\mathrm{b}=3.425 \mathrm{~A}^{\mathrm{o}}, \mathrm{c}=5.129 \mathrm{~A}^{\mathrm{o}}$ [2], $\mathrm{CuO}$ is attractive materials as a selective solar absorber since it has high solar absorbency and a low thermal emittance. $\mathrm{Cu}_{2} \mathrm{O}$ is very promising candidate for solar cell applications as it is a suitable material for photovoltaic energy conversion [3]. Polycrystalline thin and thick films of copper oxide have been prepared by various techniques such as thermal oxidation, electro deposition, chemical conversion, chemical brightening, spraying, chemical vapor deposition, plasma evaporation, pulsed laser deposition, electrodeposition, reactive sputtering and molecular beam epitaxy [4-7]. The application field of those are slightly different because of the distinct characteristic's between cuprous and cupric oxide. Copper oxide were used for gas sensors for hydrogen and volatile organic compounds, catalysis , and specially, cuprous oxide films were intensively researched in device applications such as photochromic coatings, photovoltaic solar cell [8-10]. Many authors explained the effect of annealing on $\mathrm{Cu}_{2} \mathrm{O}$ in air at temperature up to $359^{\circ} \mathrm{C}$ that cause a conversion of $\mathrm{Cu}_{2} \mathrm{O}$ to $\mathrm{CuO}$ [11,12].At higher annealing temperature, total conversion is possible to occur and $\mathrm{CuO}$ could revert

*Ministry of Since and Technology, Baghdad- Iraq. 
to $\mathrm{Cu}_{2} \mathrm{O}$. However, this possibility was not further study. In this paper, $\mathrm{CuO}$ thin films will be deposited by dipping the substrate in a solution of $\mathrm{KOH}$ at $80{ }^{\circ} \mathrm{C}$ and of a copper complex $\left(25^{\circ} \mathrm{C}\right)$, then the films well be annealed in air at temperature ranging from 200 to 400 ${ }^{\circ} \mathrm{C}$ in order to study annealing effects on the growth characteristics of $\mathrm{CuO}$ thin film as well as its structural, morphological and optical properties.

\section{Material and Methods:}

For the preparation of copper oxide thin film, two beakers are needed, first beaker contains $1.0 \mathrm{M} \mathrm{KOH}$, the second contains copper thiosulfate complex solution., in order to formed the copper thiosulfate complex solution , $\left(\mathrm{Na}_{2} \mathrm{~S}_{2} \mathrm{O}_{3}\right)$ was gradually added to $0.5 \mathrm{M} \mathrm{Cu} \mathrm{Cu}_{2} \mathrm{SO}_{4} .5 \mathrm{H}_{2} \mathrm{O}$ until a colorless solution results. A glass slide used as substrate was first cleaned with chromic acid followed by hot distilled water rinse. The first glass substrate is immersed in $80{ }^{\circ} \mathrm{C}$ of $\mathrm{KOH}$ solution for $15 \mathrm{sec}, \mathrm{OH}^{-}$ions (anion) from $\mathrm{KOH}$ solution adhered to the surface of substrate. Second immersion of glass substrate in copper thiosulfate complex solution for $25 \mathrm{sec}$, ions $\mathrm{Cu}^{+}$(cation) from copper thiosulfate complex solution as in figure (1). By repeating immersed cycles formation of colorless solution could be represented by Eq. (1) [3]:

$$
\begin{gathered}
2 \mathrm{Cu}_{2}^{+}+\underset{ }{4 \mathrm{~S}_{2} \mathrm{O}_{2}{ }^{3-} \Leftrightarrow} \Leftrightarrow 2\left[\mathrm{Cu}\left(\mathrm{S}_{2} \mathrm{O}_{3}\right)\right]^{-}+ \\
{\left[\mathrm{S}_{4} \mathrm{O}_{6}\right]^{2-}}
\end{gathered}
$$

The reaction between $\mathrm{Cu}^{+}$ion and $\mathrm{OH}^{-}$ion takes place on the substrate surface leading to the formation of copper oxide. A thin film is formed on the glass substrate, the overall reaction can be written as:

$$
\begin{aligned}
& \mathrm{Cu}^{+}+2 \mathrm{OH}^{-} \rightarrow \mathrm{Cu}(\mathrm{OH})_{2} \ldots \text { (2) } \\
& \mathrm{Cu}(\mathrm{OH})_{2} \leftrightarrow \mathrm{CuO}+\mathrm{H}_{2} \mathrm{O} \ldots \text { (3) }
\end{aligned}
$$

Annealing process was done in a furnace with temperature control.

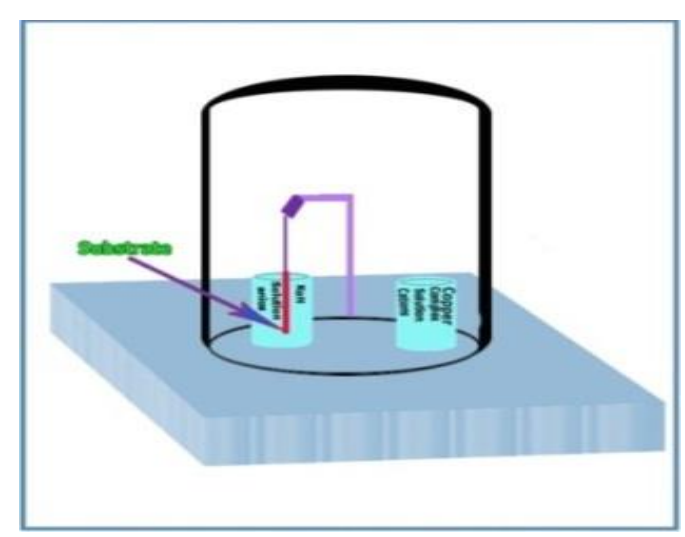

Figure. (1): Successive Ionic Layer Adsorption and Reaction (SILAR) Method

\section{3- Results and Discussion \\ 3.1 Structural analysis}

The structural elucidation of $\mathrm{CuO}$ film for the preparation condition of the films is presented in Figure (2) with diffraction $2 \theta$ from 20 to $60^{\circ}$. The observed $d$ spacing and the respective prominent peaks correspond to reflections (111), (200), and (202) planes at $2 \theta=35.5^{\circ}, 38.73^{\circ}$ and $48.6^{\circ}$ respectively, which coincide to $\mathrm{CuO}$ (XRD 6000 Shimadzu Japan data file N 1997 JCPDS prevalent).Annealing the samples in air at temperature at $(200, \quad 300,400) \quad{ }^{\circ} \mathrm{C}$ showed an increases of peak intensity which means that the crystallinity as well as the grain size of the films is enhanced. thus improve the crystalline defects disappear, continuous annealing may lead to occurs some fusion of grain boundaries resulting in a marginal, holes in the membrane surface it disappear and rid of impurities[13]. The crystallite size was calculated from the X-ray line broadening data using the Scherrer formula[14], as it shown in tables (1),(2),(3),(4).

$$
\text { G.S }=K \lambda / \boldsymbol{\beta} \cos \theta \ldots \text { (4) }
$$


Where

G.S : is average the grain size

$\mathrm{K}$ : is a constant $(0.94)$

$\lambda$ : is the wavelength of $\mathrm{Cu} \mathrm{K \alpha}$ $\theta$ : is the Bragg's angle

$\beta$ : Full Width at Half Maximum

(FWHM)of the preferential plane.

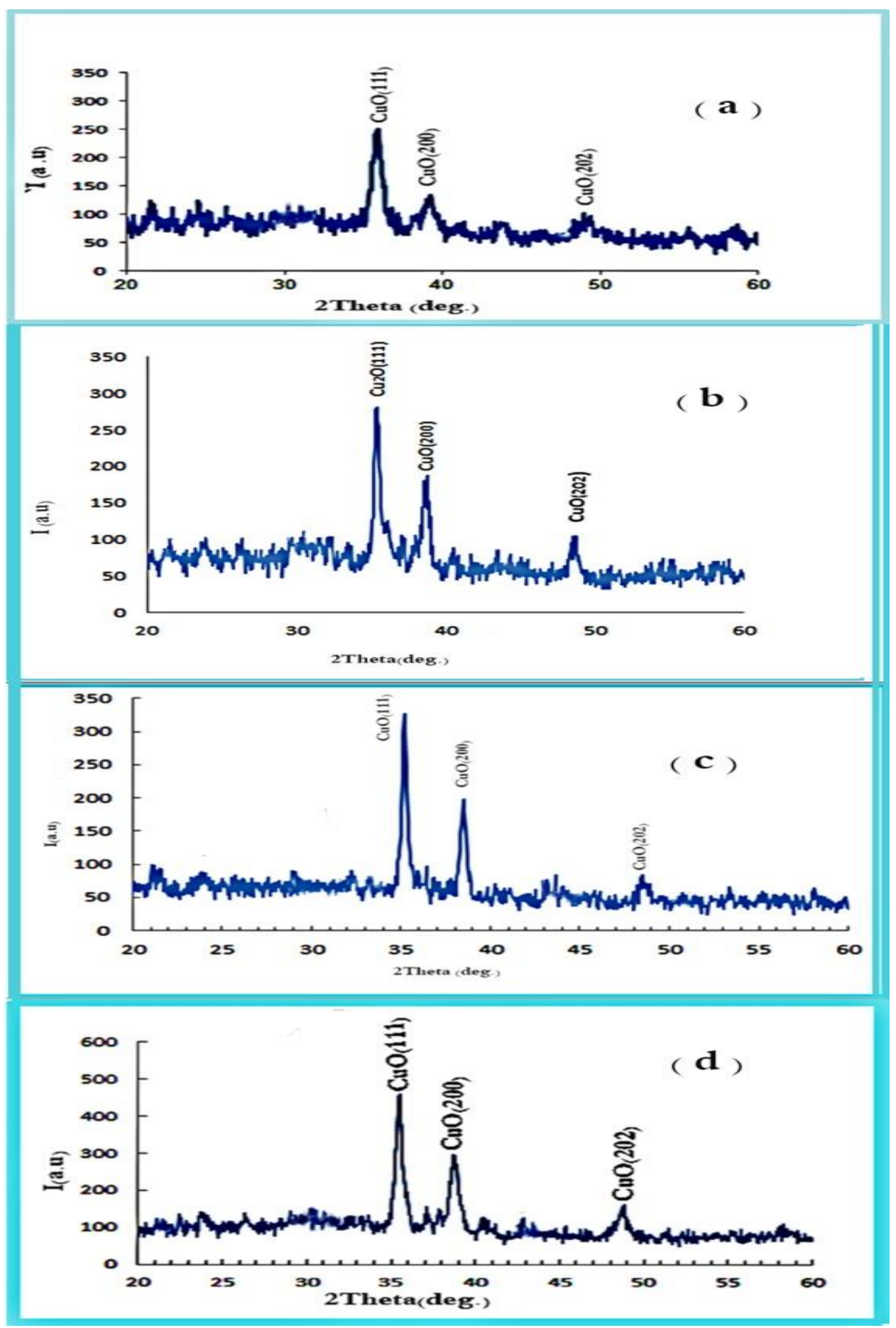

Figure (2): $\mathrm{X}$-Ray diffraction pattern and miller indices of $\mathrm{CuO}$ films prepared, (a) without annealing; (b), (c), (d) at $\left(200,300,400{ }^{\circ} \mathrm{C}\right)$ annealing temp. 
Table 1. The properties of the structural before annealing .

\begin{tabular}{|l|l|l|l|c|l|l|}
\hline sample & $\mathbf{2} \theta$ & $\mathbf{d}\left(\mathbf{A}^{\circ}\right)$ & I $($ a.u $)$ & $\boldsymbol{\beta}$ & hkl & G.S(nm) \\
\hline \multirow{3}{*}{$\begin{array}{l}\text { Oxpper } \\
\text { Oxide }\end{array}$} & $\mathbf{3 5 . 8 4}$ & $\mathbf{2 . 5 0 2 8 6}$ & $\mathbf{7 9}$ & $\mathbf{0 . 0 1 2 7}$ & $\mathbf{1 1 1}$ & $\mathbf{1 9 . 7 2}$ \\
\cline { 2 - 7 } & $\mathbf{3 8 . 2 8 5 1}$ & $\mathbf{2 . 3 4 9 0 5}$ & $\mathbf{2 9}$ & $\mathbf{0 . 0 1 2 6}$ & $\mathbf{2 0 0}$ & $\mathbf{1 2}$ \\
\cline { 2 - 7 } & $\mathbf{4 8 . 9 2 8 7}$ & $\mathbf{1 . 8 6 8 9}$ & $\mathbf{1 5}$ & $\mathbf{0 . 0 1 4 8}$ & $\mathbf{2 0 2}$ & $\mathbf{2 2 . 2 8}$ \\
\hline
\end{tabular}

Table 2. The properties of the structural after annealing at $200^{\circ} \mathrm{C}$.

\begin{tabular}{|l|l|l|l|c|l|l|}
\hline sample & $\mathbf{2 \theta}$ & $\mathrm{d}\left(\mathrm{A}^{\circ}\right)$ & $\mathrm{I}(\mathbf{a} . \mathbf{u})$ & $\boldsymbol{\beta}$ & hkl & G.S(nm) \\
\hline \multirow{3}{*}{$\begin{array}{l}\text { Oxpper } \\
\text { Oxide }\end{array}$} & $\mathbf{3 5 . 5}$ & $\mathbf{2 . 5 2 9}$ & $\mathbf{8 3}$ & $\mathbf{0 . 0 0 7 7}$ & $\mathbf{1 1 1}$ & $\mathbf{4 1 . 5 6}$ \\
\cline { 2 - 7 } & $\mathbf{3 8 . 7 5}$ & $\mathbf{2 . 3 2 1 8 6}$ & $\mathbf{4 7}$ & $\mathbf{0 . 0 1 0 0}$ & $\mathbf{2 0 0}$ & $\mathbf{1 6 . 6 9}$ \\
\cline { 2 - 7 } & $\mathbf{4 8 . 6 9 5}$ & $\mathbf{1 . 8 6 8 4 2}$ & $\mathbf{2 0}$ & $\mathbf{0 . 0 0 8 1}$ & $\mathbf{2 0 2}$ & $\mathbf{3 1 . 6}$ \\
\hline
\end{tabular}

Table 3. The properties of the structural after annealing at $300^{\circ} \mathrm{C}$.

\begin{tabular}{|l|l|l|l|c|l|l|}
\hline sample & $\mathbf{2} \theta$ & $\mathrm{d}\left(\mathrm{A}^{\circ}\right)$ & $\mathrm{I}($ a.u $)$ & $\boldsymbol{\beta}$ & hkl & G.S(nm) \\
\hline \multirow{3}{*}{$\begin{array}{l}\text { Oxpper } \\
\text { Oxide }\end{array}$} & $\mathbf{3 5 . 6 3}$ & $\mathbf{2 . 5 2 9 1 5}$ & $\mathbf{9 0}$ & $\mathbf{0 . 0 0 6 4}$ & $\mathbf{1 1 1}$ & $\mathbf{4 3 . 5}$ \\
\cline { 2 - 7 } & $\mathbf{3 8 . 7 0 8 7}$ & $\mathbf{2 . 2 9 9 2 9}$ & $\mathbf{5 0}$ & $\mathbf{0 . 0 0 9 0}$ & $\mathbf{2 0 0}$ & $\mathbf{1 7 . 5 8}$ \\
\cline { 2 - 7 } & $\mathbf{4 8 . 6 7 8 8}$ & $\mathbf{1 . 8 5 9}$ & $\mathbf{2 4}$ & $\mathbf{0 . 0 0 6 3}$ & $\mathbf{2 0 2}$ & $\mathbf{3 2 . 8 7}$ \\
\hline
\end{tabular}

Table 4. The properties of the structural after annealing at $400^{\circ} \mathrm{C}$.

\begin{tabular}{|l|l|l|l|c|l|l|}
\hline sample & $2 \boldsymbol{\theta}$ & $\mathrm{d}\left(\mathrm{A}^{\circ}\right)$ & $\mathrm{I}($ a.u $)$ & $\boldsymbol{\beta}$ & hkl & G.S(nm) \\
\hline \multirow{2}{*}{$\begin{array}{l}\text { Copper } \\
\text { Oxide }\end{array}$} & $\mathbf{3 5 . 2 3}$ & $\mathbf{2 . 5 4 2 6 3}$ & $\mathbf{1 0 0}$ & $\mathbf{0 . 0 0 5 8}$ & $\mathbf{1 1 1}$ & $\mathbf{7 3 . 3 7}$ \\
\cline { 2 - 7 } & $\mathbf{3 8 . 4 9}$ & $\mathbf{2 . 3 3 6 9}$ & $\mathbf{5 3}$ & $\mathbf{0 . 0 0 7 2}$ & $\mathbf{2 0 0}$ & $\mathbf{2 1 . 0 7}$ \\
\cline { 2 - 7 } & $\mathbf{4 8 . 3 2}$ & 1.8817 & $\mathbf{8}$ & $\mathbf{0 . 0 0 4 7}$ & $\mathbf{2 0 2}$ & $\mathbf{5 4 . 3 3}$ \\
\hline
\end{tabular}

\subsection{Broadening correction that resulting from the device:}

To find the correct size of the crystal must add a correction factor of the basic equation (4) to take into account the broadening of the XRD curve output from the device, several methods has assumed for this purpose, including:-

\section{Warren - Scherer Method:}

Warren had assumed that the mathematical representation of curves resulting from the $\mathrm{X}$-ray diffraction (XRD) depends primarily on the similarity amount among these curves and functions of each of Cauchy and Gauss. When we consider the XRD curve is similar to the Cauchy's function, which take the form $\left(1+\mathrm{k}^{2} \mathrm{x}^{2}\right)^{-}$ 1 , the broadening correction is given by the following relationship, which is called Scherer's correction.

$\beta c s=\beta m-\beta i \quad \ldots \quad$ (5) $\beta \mathrm{m}$ : Show X-ray diffraction curve in the middle of the great intensity measured in practice.

$\beta \mathrm{i}$ : Show X-ray diffraction curve in the middle of the great distress caused by the device used.

$\beta \mathrm{i}=0.11$

By compensation (5) in (4) we get

$D=K \lambda /[(\beta m-\beta i) \cos (\theta)] \quad \ldots . \quad$ (6)

In consideration XRD curve is similar to the Gauss's function which takes the form $\exp \left(-\mathrm{k}^{2} \mathrm{x}^{2}\right)$, the accuracy to be higher because of the great similarity between this function and the diffraction curves, Warren suggested the correction in the form: $\beta c s^{2}=\beta m^{2}-\beta i^{2} \ldots$ (7)

Which called Warren's Correction by compensation (7) in (4) we get?

$D=K \lambda /\left[\left(\beta m^{2}-\beta i^{2}\right)^{1 / 2} \cos (\theta)\right] \quad \ldots . \quad(8)$

The resulting line form does not resemble the Gauss's curve nor the Cauchy's curve completely, for this reason the simple relationships with 
limited practical values. If the intensity curve is non-acute, it may be used Scherer's correction or Warren's correction previously, because the difference among the given values by equations (6) and (8) is not significant, which means that the decrease in the curve broadening ( increasing the intensity) means that the effect of the amount $(\beta \mathrm{i})$ is significant, the Full Width at Half Maximum (FWHM) curve is inversely proportional to grain size as in equation 4 , the decrease
(FWHM) is a grain size increase, which means a few crystal defects. Moreover, Warren suggested a relationship takes into account the geometric meaning $[14,15]$, which is: $\beta c s=\left[(\beta m-\beta i)\left(\beta m^{2}-\beta i^{2}\right)^{1 / 2}\right]^{1 / 2}$

By compensation (9) in (4) we get $\left.\left.D=K \lambda / I(\beta m-\beta i)\left(\beta m^{2}-\beta i^{2}\right)^{1 / 2}\right]^{1 / 2} \cos \theta\right]$ .... (10).

The correction results data of the values of grain size of samples are as it shown in tables (5),(6),(7), and (8).

Table (5): The crystalline size by using Scherrer's\&Warren's correction and their comparison with Scherrer's equation before the correction at RT

\begin{tabular}{|c|c|c|c|c|}
\hline Temp. & $\begin{array}{l}\text { D(nm) } \\
\text { Scherrer's } \\
\text { equa. (4) }\end{array}$ & $\begin{array}{c}\text { D }(\mathrm{nm}) \\
\text { Scherrer's } \\
\text { equa.(6)correction }\end{array}$ & $\begin{array}{c}\mathrm{D}(\mathrm{nm}) \\
\text { Warren's equa. }(8) \\
\text { correction }\end{array}$ & $\begin{array}{c}\mathrm{D}(\mathrm{nm}) \\
\text { Warren's geometrical } \\
\text { equa. (10) correction }\end{array}$ \\
\hline \multirow{3}{*}{$\begin{array}{l}\text { Room } \\
\text { Temp }\end{array}$} & 19 & 23 & 19 & 21 \\
\hline & 12 & 14 & 12 & 13 \\
\hline & 22 & 30 & 23 & 26 \\
\hline
\end{tabular}

Table .6 The crystalline size by using Scherrer's \&Warren's correction and their Comparison with Scherrer's equation after the correction at the annealing $200 \mathrm{C}^{\circ}$

\begin{tabular}{|c|c|c|c|c|}
\hline \multirow{2}{*}{ Temp. } & $\begin{array}{c}\text { D(nm) } \\
\text { Scherrer'sequa. } \\
(\mathbf{4})\end{array}$ & $\begin{array}{c}\text { D (nm) } \\
\text { Scherrer'sequa. (6) } \\
\text { correction }\end{array}$ & $\begin{array}{c}\text { D (nm) } \\
\text { Warren's } \\
\text { equa. (8) } \\
\text { correction }\end{array}$ & $\begin{array}{c}\text { D (nm) } \\
\text { Warren's geometrical } \\
\text { equa. (10) correction }\end{array}$ \\
\hline \multirow{2}{*}{$200^{\circ} \mathrm{C}$} & 42 & 60 & 44 & 50 \\
\cline { 2 - 5 } & 17 & 21 & 17 & 17 \\
\hline
\end{tabular}

Table .7 The crystalline size by using Scherrer's \&Warren's correction and their comparison with Scherrer's equation after the correction at the annealing $300 \mathrm{C}^{\circ}$

\begin{tabular}{|c|c|c|c|c|}
\hline \multirow{2}{*}{ Temp. } & $\begin{array}{c}\text { D(nm) } \\
\text { Scherrer's } \\
\text { equa. (4) }\end{array}$ & $\begin{array}{c}\text { D (nm) } \\
\text { Scherrer's equa. } \\
(6) \text { correction }\end{array}$ & $\begin{array}{c}\text { D (nm) } \\
\text { Warren's } \\
\text { equa. (8) } \\
\text { correction }\end{array}$ & $\begin{array}{c}\text { D (nm) } \\
\text { Warren's geometrical } \\
\text { equa. (10) correction }\end{array}$ \\
\hline \multirow{2}{*}{$400^{\circ} \mathrm{C}$} & 73 & 109 & 78 & 92 \\
\cline { 2 - 5 } & 21 & 30 & 23 & 26 \\
\cline { 2 - 5 } & 54 & 115 & 70 & 92 \\
\hline
\end{tabular}

Table .8 The crystalline size by using Scherrer's\&Warren's correction and their comparison with Scherrer's equation after the correction at the annealing $400 \mathrm{C}^{\circ}$

\begin{tabular}{|c|c|c|c|c|}
\hline \multirow{2}{*}{ Temp. } & $\begin{array}{c}\text { D(nm) } \\
\text { Scherrer' } \\
\text { sequa. (4) }\end{array}$ & $\begin{array}{c}\text { D }(\mathbf{n m}) \\
\text { Scherrer's equa. } \\
(\mathbf{6}) \text { correction }\end{array}$ & $\begin{array}{c}\mathbf{D}(\mathbf{n m}) \\
\text { Warren's equa. (8) } \\
\text { correction }\end{array}$ & $\begin{array}{c}\text { D (nm) } \\
\text { Warren's geometrical } \\
\text { equa. (10) correction }\end{array}$ \\
\hline \multirow{3}{*}{$300^{\circ} \mathrm{C}$} & 44 & 58 & 45 & 51 \\
\cline { 2 - 5 } & 18 & 22 & 18 & 20 \\
\cline { 2 - 5 } & 33 & 47 & 35 & 40 \\
\hline
\end{tabular}


The dependence of grain size on annealing temperature is demonstrated in figure (3), which refers to a plot of grain size as a function of temperature for copper oxide thin films. The grain size increased slowly at first (from $52.3 \mathrm{~nm}$ to $65.5 \mathrm{~nm}$ ) whilst the grain size increased more rapidly after that (from $65.5 \mathrm{~nm}$ to $97.6 \mathrm{~nm}$ ). Grain growth rate increases more rapidly at higher annealing temperature[8].

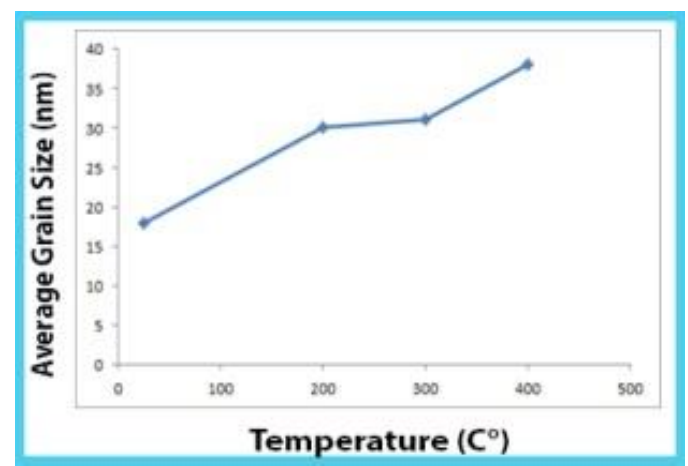

Figure (3): Grain size-temperature curve for copper oxide thin films

\subsection{The Optical Transmittance Microscopic}

Figure 4(a,b,c,d) Shows the microscopic examination of the membranes of copper oxide thin before and after annealing. The note of the shape and the presence of forest Chart refers to the stages of the growth of primitive might get of the membrane and the note after annealing the disappearance of most of the surface defects and holes and the emergence of the border beloved in a clear and this refers to the crystal structure improved of the membrane no improvement in the properties of the membranes.

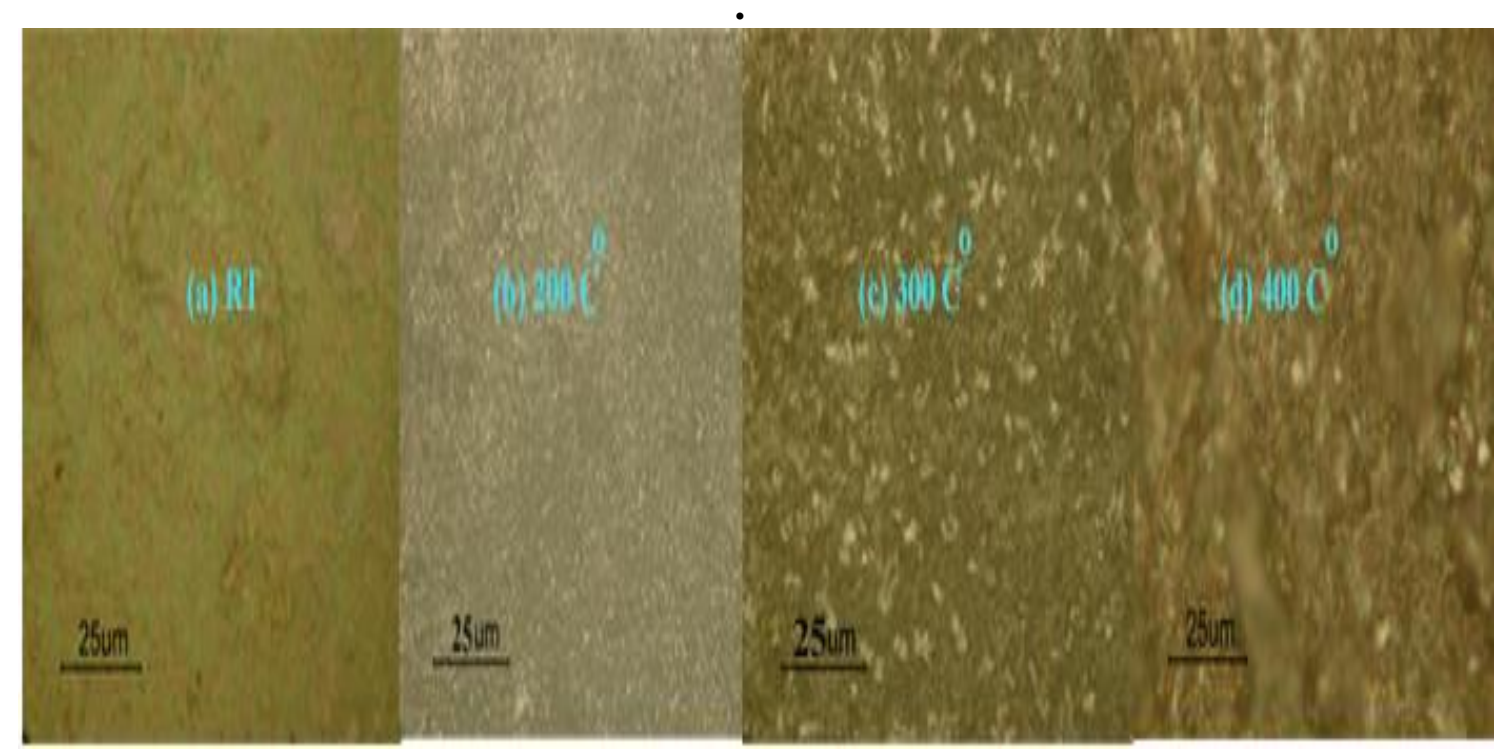

Figure (4):Optical transmitter microscope image of CuOfilms prepared, (a) without annealing; (b), (c), (d) at $\left(200,300,400{ }^{\circ} \mathrm{C}\right)$ annealing temp.

\subsection{The Atomic Force Microscopic}

AFM is a convenient and versatile method to study the microstructure of thin film. The surface morphology and roughness of $\mathrm{CuO}$ thin film is shown in figure $5(\mathrm{a}, \mathrm{b}, \mathrm{c}, \mathrm{d})$. For all samples it refers that the average grain size of thin film are between $(20-200) \mathrm{nm}$. 

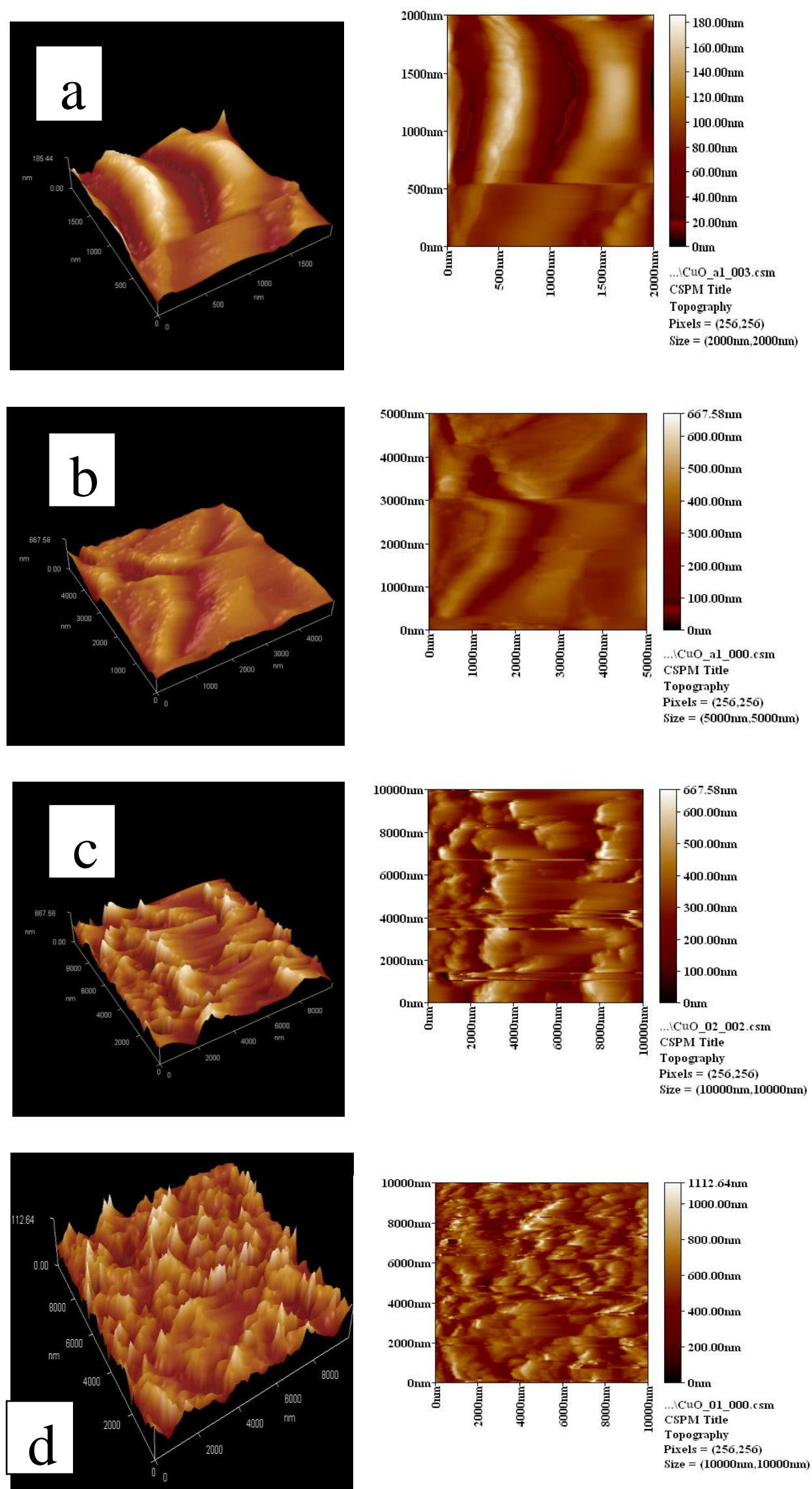

Figure (5):Atomic force microscope image of $\mathrm{CuO}$ films prepared, (a) without annealing; (b), (c), (d) at $\left(200,300,400{ }^{\circ} \mathrm{C}\right)$ annealing temp. 


\section{Optical properties}

Figure (6) shows the combination of optical absorbance spectra for all the four samples of copper oxide thickness was determined by device (MINITEST - 3000)thin films around $0.43 \mu \mathrm{m}$ thickness. The absorbance of the deposited thin film was measured using. UV-VIS spectrum (Optima Sp 300 Plus) in the wavelength region of $200 \mathrm{~nm}-1000 \mathrm{~nm}$. The optical absorbance spectra are as shown in the figure6: $(a, b, c, d)$.
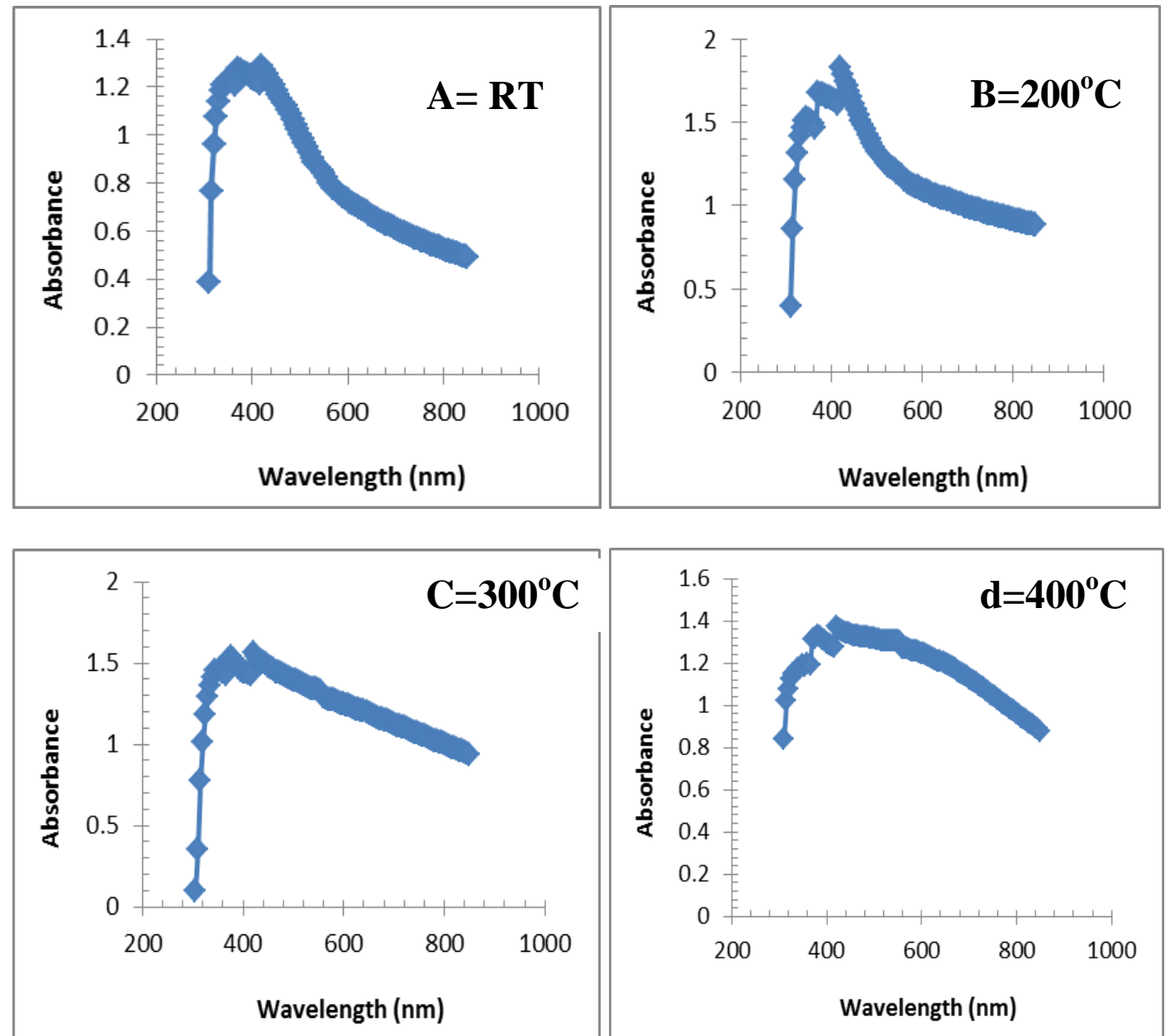

Figure 6: $(\mathbf{a}, \mathbf{b}, \mathbf{c}, \mathbf{d})$ : Absorption spectrum of annealed and reference samples of Copper oxide thin film .

Figure (7), represents the variations of the absorption coefficient with photon energy $(h v)$ for copper oxide. It is found that the absorption coefficient is increase with an increase in annealing temperature. 

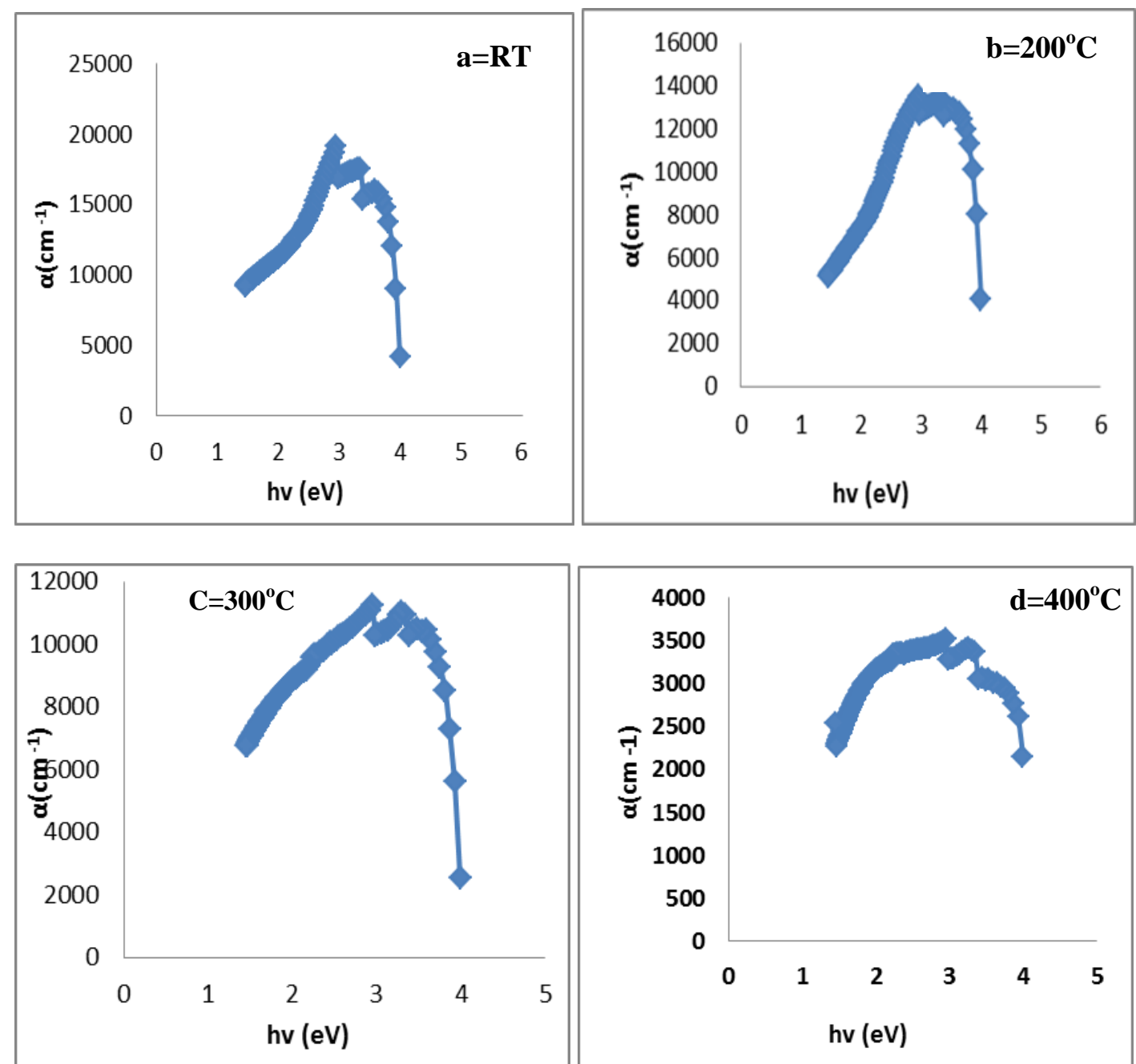

Figure 7: Absorption coefficient ( $(\alpha) v e r s u s(h v)$ curve of annealed and reference samples of Copper oxide thin films 

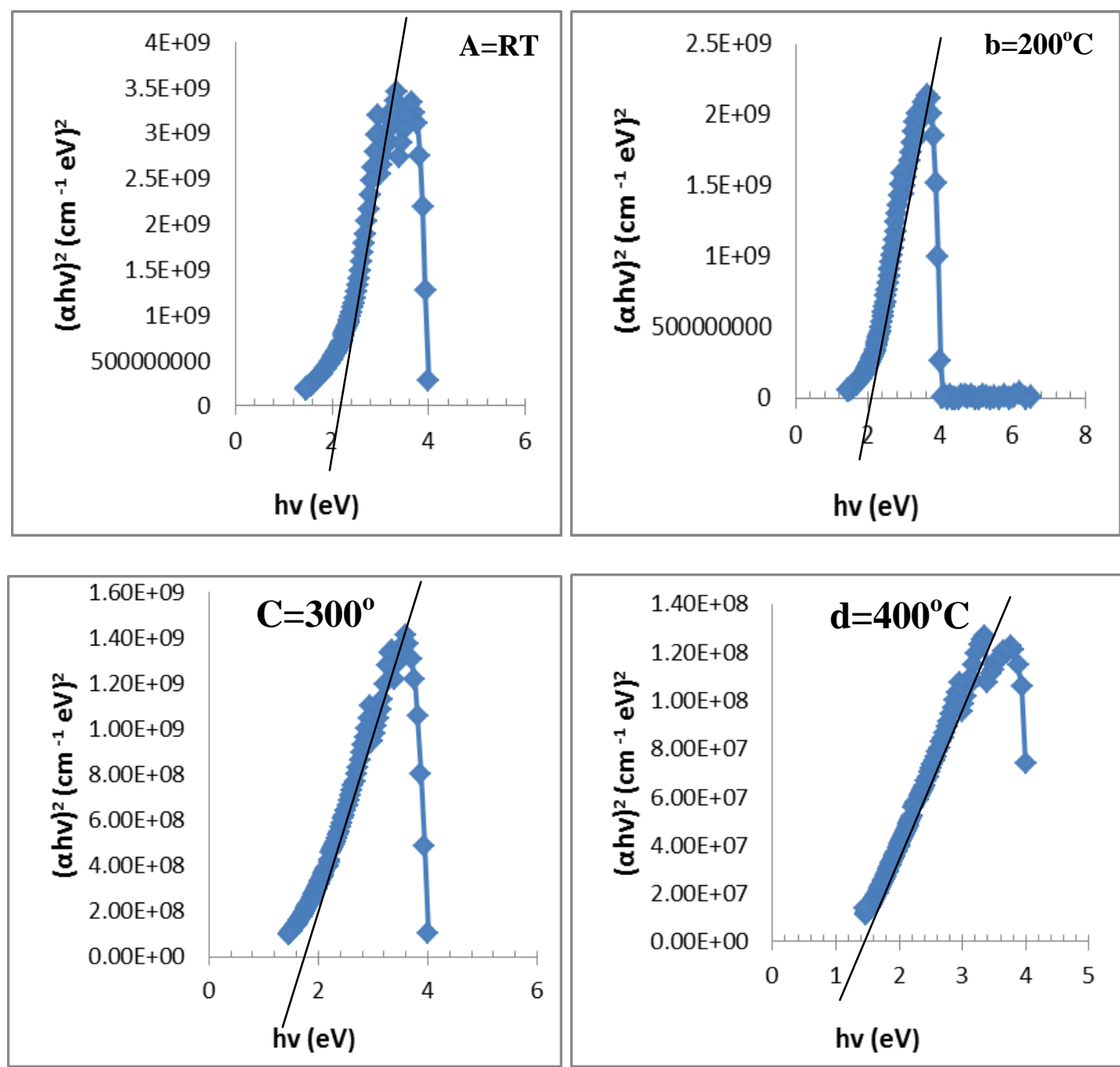

Figure 8: $(a, b, c, d):$ Plot of $(\alpha h v)^{2}$ versus (hv) curveof annealed and reference samples of Copper oxide thinfilm

Figure (8), show the variation of $(\alpha h v)^{2}$ versus $h v$ for energy band gap of the $\mathrm{CuO}$ thin films, respectively. The energy band gap $E g$ values have been determined by the extrapolation of the linear portion on the energy axis. It can be seen that the value of $E \mathrm{~g}$ decreased from $2.2 \mathrm{eV}$ to $2 \mathrm{eV}$ at $200{ }^{\circ} \mathrm{C}, 1.5 \mathrm{eV}$ at $300{ }^{\circ} \mathrm{C} 1.4 \mathrm{eV}$ and at $400{ }^{\circ} \mathrm{C}$ as shown in Table (9). The observation of figure (8) shows that the band gap energy decreases with increase in the annealing temperature, this results are agreement with other researches [8].

Table. 9 Optical band gap (Eg) values for copper oxide thin films Copper Oxide 1 Energy Band

\begin{tabular}{|c|c|}
\hline Thin Films & Gap Eg (eV) \\
\hline As-deposited & 2.2 \\
\hline $\begin{array}{c}\text { Annealed at } \\
200^{\circ} \mathrm{C}\end{array}$ & 2 \\
\hline $\begin{array}{c}\text { Annealed at } \\
300^{\circ} \mathrm{C}\end{array}$ & 1.5 \\
\hline $\begin{array}{c}\text { Annealed at } \\
400^{\circ} \mathrm{C}\end{array}$ & 1.4 \\
\hline
\end{tabular}

\section{5- Conclusions}

$\mathrm{CuO}$ thin films, deposited by the successive Ionic Layer Adsorption and Reaction (SILAR ) on glass substrates at room temperature. The crystallization is found to increase in the annealed films. AFM images also support the growth of crystallite sizes for the as-grown films and annealed 
films from (200 to 400$){ }^{\circ} \mathrm{C}$. The $\mathrm{CuO}$ films are low absorbance in the UVVisible range at as-grown films and annealing treatment causes increase in absorbance. It is observed that the allowed direct optical band gap of the films decreases from $2.2 \mathrm{eV}$ to $1.4 \mathrm{eV}$ with the increase of annealing temperature .

\section{References:}

[1]. G Papadimitropoulos, N Vourdas, V Em Vamvakas and D Davazoglou, (2005) Deposition and characterization of copper oxide thin films, Journal of Physics: Conference Series 10, 182185.

[2].Lanke U D and Vedawyas M , (1999). Preparation and characterization of nanostructured $\mathrm{CuO}$ thin films for photo electrochemical splitting of water Nucl. Instrum. Meth. Phys. Res. B155 97

[3].M. R. Johan , M. Sh.Mohd, N. L. Hawari1,H. A.Ching, Int. J. Electrochem. Sci., 6 (2011) 6094 6104.

[4]. M. Ristov, G. I. Sinadinovski, and I. Grozdanov, (1985). Chemical deposition of

$\mathrm{Cu} 2 \mathrm{O}$ thin films Thin Solid Films, 123 ,63.

[5]. M. T. S. Nair, L. Guerrero, O. L. Arenas, and P. K. Nair, (1999). Chemically deposited copper oxide thin films: structural, optical and electrical characteristics, Applied Surface Science, 150 (1999) 143-151. Appl. Surf. Sci., 150143.

[6]. Y. F. Nicolau, (1985) . Annealing Effects on the Properties of Copper Oxide Thin Films Prepared by Chemical Deposition. Appl. Surf. Sci., 22-23,1061.
[7]. D. CHAUHAN, V R SATSANGI, S. DASS and R. SHRIVASTAV, Bull. Mater. Sci., Vol. 29, No. 7, December 2006, pp. 709-716.

[8]. J. Y. Park, T. H. Kwon, S. W. Koh, and Y. C. Kang,(2011). Annealing Temperature Dependence on the Physicochemical Properties of Copper Oxide Thin Films, Bull. Korean Chem. Soc., Vol. 32, No. 4 1331-1335.

[9].Mahalingam, T.; Chitra, J. S. P.; Chu, J. P.; Moon, H.; Kwon, H. J, Kim, Y. D. (2006). Annealing Temperature Dependence on the Physicochemical Propertiesof Copper Oxide Thin Films. J. Mater. Sci.: Mater. Electron. 17, 519.

[10]. Fernando, C. A. N.; Bandara, T. M. W. J.; Wethasingha, S. K.( 2001). Annealing Temperature Dependence on the Physicochemical Properties of Copper Oxide Thin Films .Sol.Energy Mater. Sol. Cells, 70, 121.

[11]. R. Al-Gaashani, S. Radiman, N. Tabet and A. R. Daud, (2011). Annealing Effects on the Properties of Copper Oxide Thin Films Prepared by Chemical Deposition. J. Alloys and Compounds, 35 , 8761-8769.

[12]. Z. Huda, and B. Ralph, (1990). Annealing Effects on the Properties of Copper Oxide Thin Films Prepared by Chemical Deposition. Materials Characterization, 25, 211.

[13]Mardare D, Rusu GI.( 2002). Mater Lett; $56: 210$

[14]M. Ristov, G. I. Sinadinovski, and I. Grozdanov, (1985). Thin Solid Films, 123, 63.

[15]. L.V. Azarooff, " (1968). Elementary of X-Ray Crystallography “ McGraw-Hill Book Company pp.552-556. 
تأثير التلدين على الخواص التركيبية والبصرية لأغشية اوكسيد النحاس المحضر

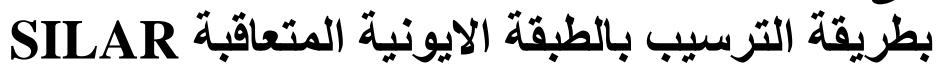

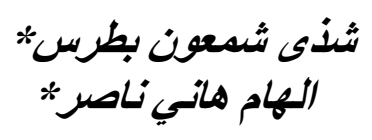

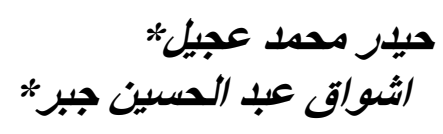

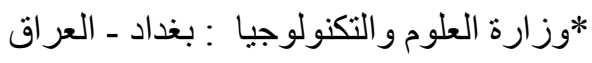

الخلاصة:

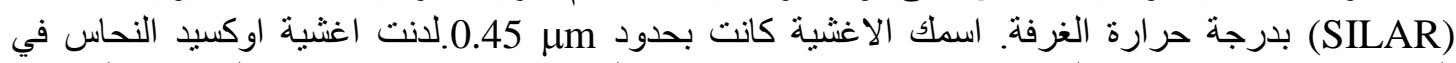

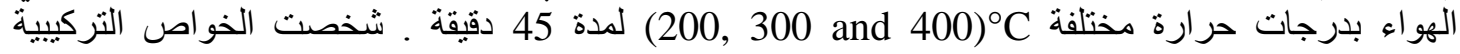

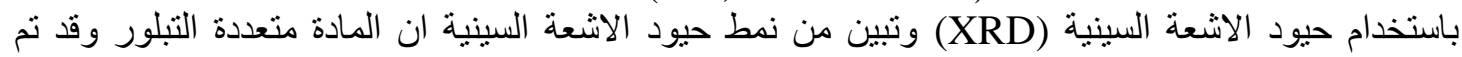

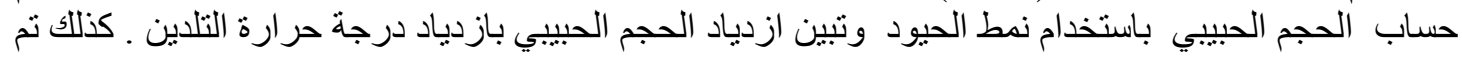

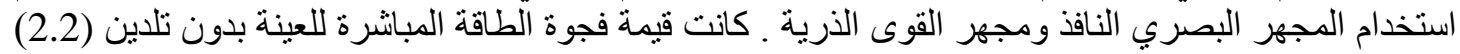

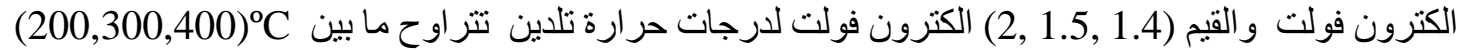
على التو الي. 